\title{
Waiting Before the Law: Kafka on the Border
}

\author{
Henk van Houtum \\ Nijmegen Centre for Border Research \\ Radboud University Nijmegen, The Netherlands
}

\begin{abstract}
In Kafka's parable 'Before the Law' the man from the country waits his entire life before the border, represented as the Law. In this article, the act of waiting before the Law is analysed in the context of a geopolitical border. More particularly, the question of why we b/order ourselves is investigated. And when do we dare to enter/ open the gate? I discuss how this act of b/ordering can be understood as balancing the desire to flee, migrate, move, escape - in short, to be freed (psychoid desire) and the desire to be, to be-long, to home oneself, to be bordered (paranoid desire). The border then is a dynamic result of our desires and of the reverse, our fears. More than a line in space, therefore, b/ordering is a strategic socio-political practice that will vary over time and space. A border is not an answer, it is a constant interrogation, for ourselves as well as others.
\end{abstract}

\section{Keywords}

before the Law, Bordering, Kafka, Ordering, Othering, paranoid desire, schizoid desire

\section{Introducing, Waiting and B/ordering}

Please allow me to start by citing that famous parable of Franz Kafka, 'Before the Law'.

Before the Law stands a gate keeper. To this gate keeper there comes a man from the country who asks for admittance to the Law. But the gate keeper says that he cannot grant admittance at the moment. The man thinks it over and asks if he will be allowed in later. 'It is possible,' says the gate keeper, 'but not at the moment.' Since the gate stands open as usual, and the gate keeper steps to one side, the man can stoop to peer through the gateway into the interior. Seeing this, the gate keeper laughs and says: 'If you like, just try to go in despite my veto. But be warned: I am powerful. And I am the meekest of the gate keepers. From hall to hall there is one gate keeper after another, each more powerful than the last. 
The third gate keeper is already so terrible that even I cannot bear to look at him.' These are difficulties the man from the country has not expected; the Law, he thinks, should surely be accessible at all times and to everyone, but as he now takes a closer look at the gate keeper in his fur coat, with his big sharp nose and long thin, black Tartar beard, he decides that it is better to wait until he gets permission to enter. The gate keeper gives him a stool and lets him sit down at one side of the door. There he sits for days and even years. He makes many attempts to be admitted, and wearies the gate keeper by his importunity. The gate keeper frequently has little interviews with him, asking him questions about his home and many other things, but the questions are put indifferently, patronizingly, and always finish with the statement that he cannot be let in yet. The man, who has furnished himself with many things for his journey, sacrifices all he has, however valuable, to the gate keeper. The gate keeper accepts everything, but always with the remark: 'I am only taking it to keep you from thinking you have omitted anything.' During these many years the man fixes his attention almost continuously on the gate keeper. He forgets the other gate keepers, and this first one seems to him the sole obstacle preventing access to the Law. He curses his bad luck, in his early years boldly and loudly; later, as he grows old, he only grumbles to himself. He becomes childish, and since in his year long contemplation of the gate keeper he has come to know even the fleas in his fur collar, he begs the fleas to help him and to change the gate keeper's mind. At length his eyesight begins to fail, and he does not know whether the world is darker or whether his eyes are only deceiving him. Yet in his darkness he is now aware of a radiance that streams inextinguishable from the gateway of the Law. Now he nears the end of his life. Before he dies, all his experiences in these long years gather themselves in his head to a point, a question he has not yet asked the gate keeper. He waves him nearer since he can no longer raise his stiffening body. The gate keeper has to bend low toward him, for the difference in height between them has altered much to the man's disadvantage. 'What do you want to know now?' asks the gate keeper; 'you are insatiable.' 'Everyone strives to reach the Law,' says the man, 'so how does it happen that for all these many years no one but myself has ever begged for admittance?' The gate keeper recognizes the man has reached his end, and, to let his failing senses catch the words, roars in his ear: 'No one else could ever be admitted here, since this gate was made only for you. The border guard is what defines himself, hence is in the end not someone else. And now, I am going to shut it.' (Franz Kafka, 1915/1998)

Maybe precisely because there is no final truth of this piece, there is no 'there' there in this text of Kafka this parable 'Before the Law' has fascinated many readers in various disciplines (see e.g. Agamben, 1995/2002; Derrida, 1992, 1994/2001). The parable is almost impenetrable, like a void, just as the Law in the story is. Hence, perhaps more than anything, the text is a mirror, an endless becoming, it fills itself with meaning by selfreflection of one's own being and b/ordering. The text is foremost a quest and a question, rather than an answer. I will use this dazzling, intriguing text of Kafka to analyse the why of borders. Kafka's quest allows me to make cross-references to the schools of thought of Nietzsche, Foucault and Deleuze who, each in their own manner, have equally been absorbed with and have aimed to find ways to understand and/or escape the subjection to a (re)pressing b/order. In short, in this short article, I aim to travel up to the border along with Kafka and some of his aforementioned previous and later fellow-travellers, and ask why and how in a regular democracy we wait at the border, and why do we thereby b/order ourselves and hence not only repress ourselves but also construct others? And is there then 
no opening of the gate possible; is there no escape from this act of waiting? What do we fear and desire when faced with the walls that we have raised around ourselves?

\section{Border Waiters}

The man from the country is waiting before the Law. He is waiting all his life to have permission to enter. It is this waiting that is most telling. For, to wait is to discipline oneself as waiting asks for a standstill, a fixation on a place and the subjection to the passing of time. It makes one aware that one is not taking part in other activities, one cannot spend time otherwise in other places, when one has decided or is forced to wait. B/ordering a geopolitical territory as well as entering it are important parts of waiting. This waiting has a double condition. For, not only the man from the country is waiting. Also the border guard stands there to wait for him. And contrary to the man from the country, a border guard is trained in the act of waiting. Border guards are in fact border waiters. They serve the border. Border guards as border waiters are, as the Greek poet Konstantínos Petros Kaváfis put it in his poem of 1904, and the writer John Michael Coetzee reminded us again in his beautiful book of 1980 with the same title, waiting for the barbarians. Kaváfis' last lines in his poem powerfully expressed the double meaning of waiting, so significant for any border: 'And now, what's going to happen to us without barbarians? They were, those people, a kind of solution'. For, as long as there are borders and border guards there will be barbarians.

As representatives of the Law, that is of state sovereignty and state power, border guards control the database of the macro-reality that is the state border, where the guards decide what is real or not and they decide who is allowed in or not. They are performing the Law. The individual is trespassing on a piece of land that they wait at, watch over and guard, day in and day out. He/she is a foreigner, not from here, who has to ask for permission to enter and for hospitality. Or, in Derrida's terms:

the foreigner is first of all foreign to the legal language in which the duty of hospitality is formulated, the right to asylum, its limits, norms, policing, etc. He has to ask for hospitality in a language which by definition is not his own, the one imposed on him by the master of the house, the host, the king, the lord, the authorities, the nation, the State, the father, etc. This personage imposes on him translation into their own language, and that's the first act of violence. (Derrida, 2000: 15)

Hence, the individual is being subjected to the legal judgment and control of the border guards that stand and wait before their gate. They have waited for the foreign subject to come, the subject was expected, not he/she in particular, but he/she as a category, as a citizen, an immigrant, refugee, lawless nomad, tourist, cross-border worker, or business traveller. They watch over their own people by watching, classifying and categorizing you as an individual who wishes to enter. A border examination is therefore, as Salter (2007a) argues, building on from the work of Agamben, a state of exception (Agamben, 2005). At the border the application of the Law for the case of the traveller is suspended in order to guarantee its existence until the case can be made applicable to the normal situation, that is, until the sovereign decides about the legality of those who wish to enter. 
The border is hence a zone, an extra-political nowhere where the sovereign exercises a decision (Salter, 2007a). As a consequence, when entering another country, another Law, one subjects oneself to the act of waiting. The man from the country has to wait. He is outside, and yet by waiting before the Law, belongs to the Law (cf. Agamben, 1995/2002). He has to wait for the border guards' permission, for his or her decision (Lugo, 2000; Salter, 2007a).

In general, in today's world, the decision for permission is increasingly based on a test. If his/her name, movements, body metrics or his/her personal luggage do not belong to their pre-given categories or look suspect to the border guards, then he/she fails their reality and reliability test. Most particularly, the border guards are trained and disciplined to wait for, recognize and filter out in the test that is the border the unlawful, the Out-Laws. Hence, for the waiting border guards, the subject is potentially an outlaw, a potentially unreliable trespasser and threat to their order. The subject is the data for the border guards, the input for their state machinery. Increasingly, a state border has become a uniformistic, digital machine, where the subject and his/her belongings will be scanned, enumerated, objectified and processed. Particularly at airports, the bordersites par excellence of our global age, this bio-metrical positivistic scanning is becoming more and more automated, resulting in scans of our faces, fingers, eyes and bodies (see also Salter, 2007b; Walters, 2006). The difference between the luggage that you carry with you that is controlled, scanned and processed and the human body has become blurred. For the border waiters at airports, your body has become a passport and the luggage in and of itself. It is this increasingly metrical border machinery which will tell you who you are, that is, which category you as a state subject belong to and if you as subject will be allowed to enter or not.

Striking then is that the suspicion, the anxiety that is created in this positivistic rite of passage that is the border control, is often internalized. For, as in a Foucauldian panopticon, the subject loses his/her privacy, and starts feeling anxious and vulnerable: he/she enters the confessionary complex (Foucault, 1977). Hence, what most commonly happens is that people passing the border will subject themselves to the mise-en-scene of the space of examination and small passage set up by the border guards, and thereby internalize the dramatic, performative script that is the border control. The wannabe-borderpasser performs hyper-authenticity, which is to be understood as a translation strategy of embodying the foreigner through the language and gaze of the host (see Jestrovic, 2008). In a way, therefore, in this micropolitics one becomes one's own gate keeper. One becomes one's own waiting act for his/her own border gate. Similarly, the man from the country is not prevented from entering, he is preventing himself, and he is disciplining, policing and b/ordering himself. There may be many possible doors in society, many possible routes to take. Yet, the man from the country has internalized the waiting for his door, he has chosen to wait before the Law, waiting to be permitted to enter the Law.

\section{Emptiness}

Implicitly building on this parable of Kafka, it was Michel Foucault (1977) who freed us from the naive assumption that political power was a 'there' there, visible at the borders or sitting in a castle somewhere in the centre (Brussels, Washington, Moscow, Beijing, etc.). 
With the building of democratic nation states, we have left the power of the One Sovereign. And with this disappearance of the aristocracy power has become less visible. It has been dispersed, diffused and scattered. The Law itself is decentred, there is no centre behind the Gate. The Law itself is empty. The modes of conduct and the ethics of being are institutionalized in the Law. The Law is hence a transcription of the societal habitus. There is nothing behind the door of our transcription, the power of the Law is what we make of the Law: the waiting. Foucault analysed a variety of power politics in and by various institutions (asylums, hospitals, academia, prison, school, family, sexuality, etc). For Foucault, the Law is a public domain, yet without any possibility of access, without a centre. The Law is beyond the reach of individual power, dis-located, receding in the outside, an intrinsic alienation. Its total powers are invisible for those standing before it:

If you like, just try to go in despite my veto. But be warned: I am powerful. And I am the meekest of the gate keepers. From hall to hall there is one gate keeper after another, each more powerful than the last. The third gate keeper is already so terrible that even I cannot bear to look at him. (Kafka, 1915/1988)

This alienation of the Law is perhaps most clearly reflected in the following meditation by Foucault on the ideas of Maurice Blanchot:

In fact, the presence of the law is its concealment. ... the law haunts cities, institutions, conduct, and gestures; whatever one does, however great the disorder and carelessness, it has already applied its might ... you might think that you have detached yourself from it and can observe its exercise from without. The moment you believe that you can read its decrees from afar and that they apply only to other people is the moment you are closest to the law ... Yet this perpetual manifestation never illuminates what the law says or wants: the law is not the principle or inner rule of conduct. It is the outside that envelops conduct, thereby removing it from all interiority; it is the darkness beyond its borders; it is the void that surrounds it, converting, unknown to anyone, its singularity into the gray monotony of the universal and opening around it a space of uneasiness, of dissatisfaction, of multiplied zeal. And of transgression. How could one know the law and truly experience it, how could one force it to come into view, to exercise its powers clearly, to speak, without provoking it, without pursuing it into its recesses, without resolutely going even farther into the outside into which it is always receding? ... That is why transgression endeavors to overstep prohibition in an attempt to attract the law to itself; it always surrenders to the attraction of the essential withdrawal of the law; it obstinately advances into the opening of an invisibility over which it will never triumph. (Foucault, in Foucault and Blanchot, 1989: 33-5)

That the Law is dis-located, decentred, does not mean that it is de-political or de-powered. To follow the Law, to 'wait before the Law' is to reproduce the Law and to make the Law powerful. The power of the Law has become what Adam Smith has described for the economic sphere: an invisible hand that guides, conducts, refrains and holds us. Hence, the internalization of the Law, the power in force, is, in the case of a democracy where the Law is indeed of our own making, not accomplished by force, but with our conscious minds and hearts. A democracy would not work if we were not complicit to the power we give to ourselves and in the names of ourselves. But that is not the 
same as saying that power is also actually in our hands. It has become omnipresent, yet empty.

And so we are continuously trained, disciplined in the waiting for the final Truth, the final judgment to come either in the form of freedom in the case of the prison, the well-educated and intelligible human in the case of school, ready for the labour market, sound and rational in the case of the madhouse, sound and better in the case of the hospital, to be examined and let through by the border guards, etc. We train and discipline ourselves and internalize the Law in the hope for liberation, in the hope to pass the test. Through its de-centralization, the Law produces a dis-placement, a dis-location of itself. It is omnipresent, yet not localizable, beyond grasp. But what is more, the emptying of the Law also produces a dis-location of those who are subjected by it. One has to wait before the Law, yet there is no entrance to it. That is, the man from the country is not yet allowed entrance. This 'not yet' for the man from the country, however, is a permanent status. It is this, the waiting before the Law and the not yet, that installs and reproduces power and creates the internalization of control. The terms waiting before the Law and not yet include a destiny, a future, a promise, a life beyond the present reality, that can only be reached through training, devotion, honesty, working or even suicide, depending on whatever the promise consists of. Hence, we are constantly waiting before the Law, and constantly reproducing the time-spatial b/order. It is the promise of good behaviour, of good internalization of the dominant order, the promise of final appreciation by the Other, that are constructing the social Self, the waiting Self. The consequence is that we live our lives in a 'not yet' status, in flux of constant be-coming, or in the words of Kafka, in indefinite postponement.

\section{The Fantasy of the Law}

The Law of the territorial border is a belief. It is a belief in the presence and continuity of a spatial binding power, which becomes meaningful and becomes objectified in our everyday social practices. The spatial separation that a border represents is goal and means at the same time (Van Houtum, 2010). A border makes and is made. A border is a verb, not a noun. As Ton van Naerssen and I have argued, we should therefore rather speak of bordering (Van Houtum and van Naerssen, 2002). To border is an act, it is a process of both internalization/subjectification of the Inside and the Objectification/ Verdinglichung/Exclusion of the Outside, the Other. The making of Border is the making of a Be-Longing into an Order, an In-group in an In-Land, and In-side; and the making of Others, is the making of a be-Longing to an Out-Group in an Out-Land, the Out-side. This act of bordering is to be understood as a continual space-fixing process which gives the impression of a finite physical process as if it concerned a physically identifiable entity with objective and unchangeable borders (see also Bauman, 1997). A border is therefore, as philosopher Peter Sloterdijk has recently argued in his book Spheres, not a military defence alone: it is also a sacred desire for eternal truth. No border is built for a short term: it is built for eternity. Knowing at the same time that there is no border in history that has not disappeared, the creation of a border is hence, as Sloterdijk argues, precisely this, a big NO against the death of the nation. It is a testament of the desired eternal life. Hence, a border is an ideology that is believed in, with the walls acting as 
the fundament of the own temple. Crucial then in the understanding of the seductive power of borders is that the constitution of a border, a shared truth, creates an immediate satisfaction for a short time, but the consequence is a long-term desire for new appropriation and control of their own truth when this truth is perceived to be threatened (Van Houtum, 2010). The desire, the wish for the (comm) unity of tomorrow, the dream of national utopia is never-ending.

That this utopian desire has or can have dystopian consequences for those who are kept outside the b/order goes without saying. The paradox is the more one waits before the Law, interpreted here as the more one internalizes a given $\mathrm{b}$ /order, and hence the more one locks oneself in, the more then that those who are kept outside the border, are locked out. Waiting before the Law and waiting outside the Law go hand in hand. Most typically, in this day and age, this waiting outside the border has taken the form and shape of asylum and detention camps.

It may be clear then that the border demarcates, represents and communicates truth, but it is not, thereby, truth itself. The emptiness of the Law produces a contingent reality and contingent rituals of truth-keeping of those who wish to maintain the constructed b/order. Borders are thus the construction of a reality and truth in a certain context, in a certain spatial entity. What is seen as truth in one domain can be a lie in the space and/or eyes of an Other. And what conventional reality is in one's own domain can be a doomed image or fantasy in the domain and/or eyes of the Other (Van Houtum, 2010). The belief in a fantasy of a true life produces the necessary illusion that what is lacking in one's identity is filled, that one's (personal) order is unified and coherent. To border oneself is to discipline oneself to an order, is to create oneself, to create a Social Self. It gives meaning to our Selves. It fills the 'holes', it makes a whole. Believing in the truthfulness of a self-devised orderly scheme of reality, be it a home, a neighbourhood, a city, a political or a religious authority, a nation, the European Union, the revolution, an after-world, a heaven or, as in the case of Kafka's parable, the Law, is believed to mean that some of the vulnerability and doubts one lives with can be reduced. Believing in the constructed and imagined community helps to gain some control over the complexities of life. Borders must therefore be seen as a strategic effort of fixation, of distanciation, of gaining control in order to achieve ease (Van Houtum and Van Naerssen, 2002).

Although the b/order is an imagined-and-lived reality, and there is an obvious price to pay for those who are kept outside, in general, that does not stop the desire for the true $\mathrm{b}$ /order. Yet, the true b/order has no end, for realizations of wholeness never align with the fantasy perfectly. The perfect identity is always there, beyond the threshold, beyond the gates of the Law. The identity is the desire of a Self or Order that is an unattainable Other. That means that the lack of fulfilment is perpetual and the final Truth of the b/ordered Self is unattainable. In the words of the guard standing before the Law in Kafka's parable: 'you are insatiable'. The man from the country is waiting before the Law, and by internalizing and believing in the fantasy of the Law he has found a pseudo-home, an in-the-meantime-home at the gate, yet his desire to unmask the void, to have access, to know the Truth, to finally become, to truly come Home, is insatiable. This feeling of endlessness is also constructed by the gate keeper who warned him already at the beginning of his life, when he first sought permission to enter, that there is no end indeed in searching for the Truth, for after the first gate keeper there are only more gate keepers, even more powerful and harder to get past than him. There is no final Truth. We remain Outsiders to our own lives, our whole lives. One 
cannot enter definitely and for ever into one's own Law. There is no final Homecoming. To fill that lack in the meantime, we create a fantasy-home by waiting before the Law, a simulacrum-home. Hence, we necessarily live in a condition of not yet and never will be. We are unavoidably living in the meantime. We are unavoidably waiting before the Law.

\section{Escape}

Needless to say, this waiting, this eternal internal disciplining is not accepted all the time or by all. There is a continuum that varies from hard-line believing to hard-line resisting, one could say. The true believers at a given time, they who have fully internalized a given order, consider themselves as the pure and authentic people of the dominant territorial order. In the case of a nation for instance, they are the 'true' nationalists or in the case of neo-liberalism as the dominant paradigm, the 'true capitalists'. At the other end, there are, at any given time, actants of resistance against the dominant order, be it against the nation, against communism, neo-liberalism or globalization (the anti-globalists). For the actants of resistance usually argue that it is society that is the evil doer and that the subject is downplayed and aggressively and unwillingly manipulated and/or that outsiders are unjustifiably kept outside the Law. For the resistors, uncritically internalizing the b/ordered society is like living in a lie, implicating a constant struggle and personal warfare. Exemplary in this respect are the words of the critical thinker Chantal Mouffe: "society is the illusion ... that hides the struggle and antagonism "behind the scenes", putting the "harsh reality" of antagonism behind a "protective veil"" (Mouffe, 1993: 51, 53).

Perhaps most powerfully, it was Nietzsche who expressed his discontent with, and critically analysed, the omnipresence of absence and feared the false truth of emptiness of his time like in a horror vacui. Nietzsche reserved the word 'nihilism' for this nothingness, the emptiness that he saw around him. For Nietzsche, with the 'death of God', and with him the One Sovereign, the Universal Law, people in his society had come to live in a nihilistic time. For him the emptiness created after the death of God was so powerful that it resulted in lethargy towards life and a suffocation of the human spirit. Nietzsche's analysis of the emptiness and devaluation of life has much in common with the thought of scholars in other times, like Rousseau, Marx and Foucault. What these scholars share is that for them freedom is the natural condition, yet we are alienated, disciplined, fixated and subjectified by the emptiness of the Truth that society commonly offers us. Arguing against the Enlightenment, all these scholars held that the real truth, the real liberation, does not come from rationalism and modernity, for that is nothing more than colonialism and subjectification. The freedom and Truth that the Enlightenment and modernity give us, are a freedom in which a human being is taken hostage by her/his rationality and consciousness. Hence, their plea is to end the alienation, to end the phantom-pain of our life not lived, and to truly free ourselves from the Truth that is offered to us by a disciplining societal order. Ergo, for Nietzsche the most important question in this context, which was later repeated by Safranski (1990), is: how much truth do we need?

It is well-known that Nietzsche advocated a remedy, an escape from this emptiness, this void (Nietzsche, 1966/1987). One of the key theses in his works is that nihilism's destructive effects could and should be overcome in the transcendence to Übermensch. The Übermensch is then characterized as someone who possesses the 'will to power', who 
affirms life, acts out of passion, creates spirit and love. The Übermensch acts above and beyond oneself. Becoming an Übermensch is an act of self-overcoming. In the eyes of Nietzsche, this Übermensch is best compared with the Greek God Dionysus, the God of liberation from one's normal self (Nietzsche, 1966/1987). This Dionysus is then to be contrasted with the weak-willed human, who denies life, who seeks only order, comfort and security. This passive human, for Nietzsche, is represented by the Greek God of Apollo, the God of pure form, symmetry. Whereas the Dionysian presents fluidity, formlessness, streams, flows, the Apollonian will in life represent form, borders, contours and determinacy. According to Nietzsche, it is the weak-willed human who borders, suppresses and disciplines himself through fantasies of hierarchical order instead of creating himself. Nietzsche calls this passive Apollonian 'the last man'. His argument then is that Western civilization is moving in the direction of the last man, for whom nothing matters, who has no great passion or commitment, who is unable to dream and create, who lives in a sphere of value-less comfort, the time-space of nihilism. Famously, Nietzsche attacked the purified, fearful, conservative, religious and orderly time-space of his time because of the element of self-denial. The death of the belief in a world of God that transcends man should be replaced by a rebirth of man himself. Hence, the plea for a creative liberation from Truth, for the use of the energy of primitive impulses, for non-reflection, for non-ordering, for dance, ecstasy, a trance that would lead to the transcendence of man himself. It is the movement from the emptiness of a time-space in which God is declared dead, the time-space of zero, the nihil, the abyss, the void, to the state of being one with oneself, to become an Übermensch. ${ }^{1}$ In a way, therefore, Nietzsche's project is about the self-enlightenment of the enlightenment, about pointing at the borders of enlightenment, the borders of Truth, the ratio, the Law (Safranski, 2000).

This desire for transcendence, to transcend the borders set out by the Law, to enter the gate, is lucidly present in the parable 'Before the Law' from Kafka. But crucially in Kafka's story, the man is waiting. He does not liberate himself. He does not escape. Seen in this light, Kafka's parable is in fact a testament of the Subject. The man from the country denies life by waiting his entire life before the Law.

Michel Foucault also focused on analyzing the various subjectification and internalization politics of institutions, thereby implicitly declaring the death of the individual. Implicitly following Nietzsche's Dionysian desire, in his later works Foucault tried to theorize the practices and strategies of rethinking oneself, of liberation and desubjectification, the ethical self, or what he labelled the 'aesthetics of existence', expressing the need and the power to free oneself from the internalization of the silencing and suffocating emptiness. Or in the words of the Greek poet Konstantínos Petros Kaváfis in his poem 'Walls', written in 1896:

Without reflection, without mercy, without shame, they built strong walls and high, and compassed me about.

And now I sit here and consider and despair.

My brain is worn with meditating on my fate:

I had outside so many things to terminate. 
Oh! why when they were building did I not beware!

But never a sound of building, never an echo came.

Out of the world, insensibly, they shut me out.

(Cavafy, 2003)

Perhaps most powerfully, however, Nietzsche's theorization of the Dionysian will to power that moves above and beyond the Apollonian will, was used by Deleuze and Guattari. Using a powerful new vocabulary, they have made it their theoretical goal in life to theorize this Nietzschean aspiration for the non-fascist nomadic, the escape from desiring our own repressive order (Deleuze and Guattari, 1972/2004, 1980/2004). For Deleuze and Guattari there is an internal struggle between order and flight, the above-mentioned Nietzschean Apollonian and Dionysian will in human life. Each human moves then between these two poles, what they label as the schizoid desire, and the paranoid desire. And these desires are socially produced. Society in their eyes is a desire-machine. On the one hand there is the productive schizoid desire of becoming and transcendence, to be 'far-sick', to desperately long-to-be somewhere else, to experience and live the personal freedom despite or thanks to the fear of the unknown, the nonroutine. This is the desire to long for emptiness at the Other side, to de-border oneself, to turn to the Other, to a longing for the Other in oneself, to become a stranger oneself. This desire is what Deleuze and Guattari refer to as the figure of the Nomad. On the other hand, there is the paranoid desire, to be homesick, to desire for order, easiness, nihilism, control, security, comfort, hence the desperate desire for the truth here, the desire for self-repression and disciplining. It is this desire that Deleuze and Guattari also refer to as the figure of the Monad, meaning an impenetrable indivisibility, a universal essence. The law of the territorial border then is the constantly moving navigational route that is the result of sailing between, on the one hand, the Scylla of the free but Law-breaking anti-social, and, on the other, the Charybdis of the social but self-repressed. In other words, the border, principally, is Janus-faced. Janus was the Roman God of the end and the beginning, of the passage, of the guard between the world above and the nether-land. Janus has two faces, the centripetal, inward-oriented and the centrifugal, the outwardoriented face. The crucial question then to answer is which face of Janus are we showing today, and why?

\section{No End}

The border that stands in between the man from the country in Kafka's parable and the space across the border which he dares not to cross is a question of: by which face do we represent ourselves, and which one do we turn towards the Other, the face of fear or of desire? The border therefore questions the Truth in oneself, the Truth of the internalization of power. The border questions the desire to internalize the Law, to internalize the b/order, to be subjected, to be-long to this side of the gate, to be a subject made to wait for the promise that is implicit in the bordering of any space: to wait for tomorrow, the near future, the fulfilment of the dream that is order. This waiting is liberating, it gives one a 
task, a meaning, a social function and a potential identity. At the same time, the identification of oneself as a subject is also a form of containment, an imprisonment of one's multiplicity in a spatially ordered box set out by others, which is the act of waiting. The sentence of imprisonment is precisely this: waiting for the Law to be merciful, waiting for the gates to be opened. The man from the country grows roots in waiting. Thus, the act of waiting at the border as a subject is at the same time an act of liberation as it is an act of containment.

Crucially then, man navigates between two poles of desire. The paranoid desire at one end is the desire for the fulfilment with total(itarian), purifying order. This desire is at the same time a fear. It is the fear of the Dionysian Overman, the NoMad, the NoMan, the noWhere, the noNow, the spatio-temporal emptiness. The fear here is to be overwhelmed by emptiness, by a barbaric madness of total freedom, the fear not to have and be without a b/order, to become a stranger (to) oneself, and to be non-existent, to be, as Giorgo Agamben puts it, profane, to become like the Law itself, pure but empty, a man without content (Agamben, 1999). And this fear, as argued above, could lead to a serious antiliberation such as containment, of those who are feared at a given time and in a certain context. At the other end, there is schizoid desire, a longing for emptiness, to estrange oneself, to distance oneself, to free oneself from the surrounding silencing walls, to be outside the Law, an out-Law, to be without the repressive social mask, to be a naked man. The fear here is to be suffocated by a repressive total monadic love, the fear for the lie of the border, to be caged by a communal order, the fear to become a Subject, to alienate oneself from the transcendent self, to deny life.

Both ends, the totalitarian, pure monadic order, as well as the totally nomadic schizoid cannot be reached. The border, the threshold that stands in between oneself and one's own other, is an endless desire for fulfilment. Man is nowhere finally at home. And hence, there is no end of fearing and desiring. As Kafka (1990) himself argued: 'My fear ... is my substance, and probably the best part of me'. On this continuum, the delineation of the border is, thus, ongoing and dynamic, crucially contingent on our own co-production of our fears and desires.

And so I end without an end. I end with a question. In order to understand why we b/order ourselves and Others in a regular democracy, and thereby define who we are, it is crucially important to understand where we are, where we stand before the Law. The border is not a beginning, nor an end, but a continuous introspective question. That is the question, what is it that we fear? And what do we desire? Where are we located on the continuum of waiting before the Law and transcending it? Where do we draw the line? The border gate is hence, as Kafka challengingly posed in his parable cited above, our own gate: 'No one else could ever be admitted here, since this gate was made only for you'. So, before the gate will finally be shut for us then, the question constantly begs our attention what we are waiting for all our lives. At what price for ourselves and others. And whether in the end that justifies the waiting.

\section{Acknowledgements}

The author wishes to thank Sarah Blandy and David Sibley for organising a wonderful conference on "theorising boundaries" in Leeds some time ago at which the first ideas 
for this paper have been presented. David Newman is thanked for organising a highly inspiring international conference on borders in Israel at which further ideas for this paper have been presented and discussed. And Johan Schimanski and Stephen Wolfe and the other members of the Border Aesthetics research project are much obliged for a lively and interesting skype chat on the issue of waiting in general and the draft of this article in particular.

\section{Note}

1. Looking at it from this angle, it may be illustrative that the territory on which the Twin Towers of the World Trade Center were standing was called 'Ground zero' after their destruction on 9/11. Here too a need was felt to overcome the darkness, the abyss and the terror and to move from zero to a state of transcendence in which the US stood tall and united again.

Nor is it a coincidence that in the impressive movie series of The Matrix, the rescuer of (Western) civilization has characteristics of an Übermensch and is called 'the One' (Neo).

\section{References}

Agamben, G. (1995/2002) Homo sacer, de soevereine macht en het naakte leven, translated by Ineke van der Burg as Homo Sacer: Il potere sovrano e la nuda vita. Boom: Parresia.

Agamben, G. (1999) The Man Without Content. Stanford, CA: Stanford University Press.

Agamben, G. (2005) State of Exception, translated by K. Attell. Chicago: University of Chicago Press.

Bauman, Z. (1997) Postmodernity and its Discontents. New York: University of New York Press.

Cavafy, C. P. (2003) Poems, translated by J. C. Cavafy. Athens: Ikaros. Available at: http://d-sites. net/english/cavafy.htm

Coetzee, J. M. (1980) Waiting for the Barbarians. London: Secker and Warburg.

Deleuze, G. and F. Guattari (1972/2004) Anti-Oedipus. Vol. 1 of Capitalism and Schizophrenia. London and New York: Continuum. [Translation of Anti-Oedipe. Paris: Les Editions de Minuit.]

Deleuze, G. and F. Guattari (1980/2004) A Thousand Plateaus. Vol. 2 of Capitalism and Schizophrenia. London and New York: Continuum. [Translation of Milles Plateaux. Paris: Les Editions de Minuit.]

Derrida J. (1992) 'Before the Law', pp. 181-220 in D. Attridge (ed.) Acts of Literature. New York: Routledge.

Derrida, J. (1994/2001) De kracht van wet; het 'mystieke fundament van het gezag'. Kampen: Agora/Pelkmans. Translation of Force de loi, le 'fondement mystique de l'autorite'. Paris: Éditions Galilée.

Derrida, J. (2000) Of Hospitality. Stanford, CA: Stanford University Press.

Foucault, M. (1977) Discipline and Punish: The Birth of the Prison, translated by A. Sheridan. London: Allen Lane, Penguin.

Foucault, M. and Blanchot, M. (1989) Foucault/Blanchot: Maurice Blanchot: The Thought from Outside by Michel Foucault; Michel Foucault as I Imagine Him by Maurice Blanchot, translated by J. Mehlman and B. Massumi. New York: Zone Books.

Jestrovic, S. (2008) 'Performing Like an Asylum Seeker: Paradoxes of Hyper-Authenticity', Research in Drama Education 13(2): 159-70. 
Kafka, F. (1990) Letters to Milena, translated by Philip Boehm. New York: Schocken Books.

Kafka, F. (1915/1998) 'Before the Law', in The Trial. New York: Schocken Books.

Lugo, A. (2000) 'Theorizing Border Inspections', Cultural Dynamics 12: 353-73.

Mouffe, C. (1993) The Return of the Political. London: Verso.

Nietzsche, F. (1966/1987) De geboorte van de tragedie, Amsterdam: International Theatre Bookshop. [Translation of Die Geburt der Tragödie.].

Safranski, R. (1990) Wieviel Wahrheit braucht der Mensch? Munich/Vienna: Carl Hanser Verlag.

Safranski, R. (2000) Nietzsche. Biographie seines Denkens, Munich/Vienna: Carl Hanser Verlag.

Salter, M. (2007a) 'We Are All Exiles: Implications of the Border as State of Exception', paper presented to the Standing Group on International Relations Conference, Italy.

Salter, M. (2007b) 'Governmentalities of an Airport: Heterotopia and Confession', International Political Sociology 1(1): 49-66.

Sloterdijk P., (2003), Sferen I en II, Boom: Amsterdam (translation of: Sphären I, 1998 and II, 1998, translation by Hans Driessen) Sloterdijk P., (2009), Sferen III, Boom: Amsterdam (translation of: Sphären III, 2004, translation by Hans Driessen).

van Houtum, H. (2010, forthcoming) 'The Mask of the Border', in D. Wastl-Walter (ed.) The Ashgate Research Companion to Border Studies. Farnham: Ashgate.

van Houtum, H. and T. van Naerssen (2002) Bordering, ordering and othering, Tijdschrift voor Economische en Sociale Geografie (TESG) 93(2): 125-36.

Walters, W. (2006) 'Border/control', European Journal of Social Theory 9: 187-203. 